\title{
Effectiveness of Interventions To Enable Hypertension Medication Adherence In Low-And Middle-Income Countries: A Systematic Review And Meta-analysis
}

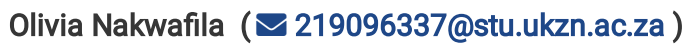

University of KwaZulu-Natal College of Health Sciences https://orcid.org/0000-0002-1447-6056

Benn Sartorius

Oxford University: University of Oxford

Sphamandla Josias Nkambule

KwaZulu-Natal Department of Health

Tivani Mashamba Thompson

University of Pretoria

Research

Keywords: Hypertension, Adherence, Randomised controlled trial, Effective interventions, Low and middle income countries, Systematic review

Posted Date: September 15th, 2021

DOI: https://doi.org/10.21203/rs.3.rs-856012/v1

License: (c) (i) This work is licensed under a Creative Commons Attribution 4.0 International License. Read Full License 


\section{Abstract}

Background: In recent decades low- and middle-income countries (LMICs) are witnessing an increase in hypertension and thus becoming a significant public health issue due to associated Cardiovascular disease (CVD) outcomes. Antihypertensive medication adherence is crucial to controlling blood pressure; therefore, this systematic review aimed to evaluate the effectiveness of non-pharmacological interventions on improving blood pressure control and medication adherence in patients with hypertension in LMICs.

Methods: We searched the following databases for relevant literature published between Jan 2005 - Dec 2020: PubMed, EBSCOhost included Academic Search; CINAHL and MEDLINE complete; PubMed; WEB of Science; Cochrane Central Register of Controlled Trials; Cochrane Database of Systematic Reviews and Google Scholar. Cochrane risk of bias tool (RoB 2) was used to appraise included studies critically, and the Grading of Recommendations, Assessment, Development and Evaluation (GRADE) was used to measure the quality of evidence. We conducted a meta-analysis using DrSimonian-Laid's random-effect model at 95\% confidence intervals (Cls). The secondary outcomes of interests were synthesised descriptively as changes in BP adherence outcomes.

Results: We identified 14 eligible randomised controlled trials that presented blood pressure (BP) effectiveness and medication adherence among BP patients aged between 18-75 years. The overall quality of evidence with the majority of trials was moderate. Meta weighed effect (SBP) for $12 / 14$ studies was -4.74 (95\% Cl:-6.07 to -3.47$)$ and $\mathrm{I}^{2}=57 \%$. Out of 14 eligible studies, (86\%) suggested a significant improvement in the proportion of patients with controlled blood pressure (BP $<140 / 90 \mathrm{mmHG})$ with a positive effect on secondary outcomes such as quality of life.

Conclusion: Non-pharmacological interventions could be effective in managing hypertension. In recommending the need to investigate the feasibility of non-pharmacological evidence in specific LMIC settings, focus should be on an intervention strategy consisting of an educational intervention directed toward the patients, health professionals and organisation. Considering heterogeneity, randomised trials that are welldesigned with larger sample sizes are encouraged in LMICs` to help policymakers make well-informed decisions on hypertension management.

Systematic review Registration: PROSPERO registration number: CRD42020172954

\section{Introduction}

Hypertension is one of the leading risk factors for CVD worldwide [1-4]. Low- and middle-income countries have seen an increase in hypertension in recent decades, thus, making it a significant public health issue due to the associated adverse health outcomes such as the increased incidence of CVD accounting for 75\% of the global deaths in LMICs (82\% attributed to coronary heart disease (CHD), stroke and heart failure) [5-8]. Despite some LMICs offering universal access to hypertension medication, including Namibia, adherence to chronic medication remains a problem [6, 911]. Recent data shows that CVD in Namibia accounted for $21 \%$ of annual deaths and a reported prevalence of blood pressure (BP) among women and men aged 35-64 at between $44-57 \%[12,13]$. Thus, it would appear that the prevalence of hypertension in Namibia is high compared to the global and African regional prevalence of $22 \%$ and $27 \%$, respectively[14]. Non-adherence to antihypertensive medication is common and contributes to poor BP control and adverse health outcomes [15]. While it is substantial to understand the barriers and enablers of non-adherence, it is equally important to explore different interventions' effectiveness on improving BP control and BP medication adherence [15-17].

Non-pharmacological interventions to encourage BP medication adherence include educational interventions directed towards the patients, educational interventions directed towards the health professional, appointment reminder systems/models, and Organisational interventions [10, 18-23]. These Interventions intentionally target non-adherence contributing factors at different levels: patients, health care workers, and the health care system[24, 25]. Many Higher-income countries have conducted extensive research on hypertension effective interventions [26, 27]. However, we cannot say the same about LMICs, especially in sub-Saharan Africa [28].

Due to the scarcity of evidence on effective interventions in LMIC's, thus far has caused a rise in CVD due to non-adherence despite pharmacological efforts [27, 29]. The contradictions around effective interventions for BP continue based on evidence conducted from several reviews such as Cochrane [20]. Henceforth it is essential to systematically review interventions that can effectively be beneficial to LMICs and help inform the feasibility of possible country-specific BP interventions that are effective.

Non-adherence, which usually occurs when BP patients fail to meet treatment goals [20], causes uncontrolled high blood pressure(Systolic blood pressure/SBP; Diastolic blood pressure/DBP) ( above 120/80), which increases the risk of severe health problems, including heart attack and stroke [30]. Data regarding BP medication adherence in Namibia is minimal, with one study spanning a sample of public health facilities in the Khomas region (capital region) reporting suboptimal adherence in 2017 [17]. Effective, widely available, low-cost, and sustainable strategies are needed to prevent and manage hypertension [15]. Existing systematic reviews on interventions have recommended that adequate control of hypertension in developing countries could be achievable by community-based programs and by upgrading primary health systems [16, 17, 29]. A critical barrier to scaling up the literature suggests a greater need to identify the optimal and effective way to organise and deliver care to hypertensive patients in LMIC's in order to improve BP medication adherence $[19,20]$. 
Benefits associated with blood pressure lowering include a reduction in many complications such as stroke (35-40\%), heart attack (20-25\%), and heart failure (over 50\%) [22, 23]. Achieving the WHO global target of a $25 \%$ relative reduction in the risk of premature mortality from NCDs by 2025 and the SDG target of a one-third reduction in premature deaths from NCDs by 2030 requires hypertension management interventions. Therefore, this systematic review aims to evaluate the effectiveness of non-pharmacological interventions on improving blood pressure control (Primary Outcome) and medication adherence (Secondary Outcome) in patients with hypertension in LMICs. We anticipate that the results from this study will provide current evidence on effective hypertension strategies targeted at controlling hypertension and CVD in LMIC settings.

\section{Methods}

A study protocol was developed prior to the conduct of this review. The protocol is registered in the PROSPERO international prospective register of systematic reviews and is accessible via the link below: https://www.crd.york.ac.uk/prospero/display_record.php?ID=CRD42020172954. The Centre for Reviews and Dissemination (CRD) guideline for systematic reviews in health care guided this study, following the Preferred Reporting Items for Systematic Reviews and Meta-Analysis (PRISMA) guidelines[31, 32]. Completed PRISMA checklist (see Additional file 1).

\section{Identifying the research question}

The identifying research question was the effectiveness of interventions to enable Hypertension Medication Adherence in LMICs.

\section{Eligibility criteria}

A Complete inclusion and exclusion criteria form part of this review protocol, registered with (PROSPERO; CRD42020172954).

We included studies published from 2005 which met the following criteria: Hypertensive patients over 18 years of age and above, regardless of sex and ethnicity with a diagnosis of primary hypertension in a specified geographically defined LMIC setting; randomised controlled trials (RCTs) of hypertensive patients which evaluated non- pharmacological effectiveness of the following interventions to improve BP medication adherence: educational interventions directed to the patient, educational interventions directed to the health professional, self-monitoring, models on appointment reminder systems, organisational interventions aimed at delivery care.

We excluded RCTs' not reporting evidence from LMIC settings published before 2005 and non-randomised controlled trials. Exclusion criteria also included studies reporting on other chronic illnesses, not reporting non-pharmacological effectiveness, and BP medication adherence outcome.

\section{Search strategy for the identification of relevant studies and information sources}

After consulting with an information scientist at the Department of Library Services, Faculty of Health Sciences, and the University of KwaZuluNatal on literature search approaches, search strategies were developed based on the Cochrane Handbook of Intervention Guidelines and the Cochrane Central Register of Control Trials. To find relevant literature, we used the following keywords: hypertension or blood pressure, LMICs, adherence or compliance, control or monitoring, Educational, patient, Self-monitoring, health professional, reminder systems, organizational, delivery care. The Boolean search terms (AND OR) and MeSH terms were employed. A search of the following databases was performed in March 2019 and repeated in December 2020: PubMed, EBSCOhost included Academic Search; CINAHL and MEDLINE complete; PubMed; WEB of Science; Cochrane Central Register of Controlled Trials; Cochrane Database of Systematic Reviews and Google Scholar. Additionally, we searched Grey literature from university dissertations and theses from institutional repositories to retrieve relevant articles. We searched for randomised controlled trials conducted from January 2005 - December 2020 to capture the recent evidence on the effectiveness of hypertension interventions available in LMIC's. There was no language restrictions applied to the search.

\section{The search management}

After a rigorous, intensive search, we exported relevant articles to the Endnote X9 library. Following the import of relevant articles by title relevance, we removed duplicates before the abstract screening stage. We then conducted a selection of abstracts and full articles using eligibility criteria utilizing abstract and full title screening forms developed in Google (see Additional file 2) for identified articles and the date of each literature searching of each database. Independent reviewers (ON and PN) did the article screening. The third screener (SN) was involved in resolving discrepancies. Subsequently, we assessed disagreement using Cohen's Kappa coefficient (K) statistic on Stata 13.0SE (StataCorp College Station, TX, USA (Additional file 3).

\section{Data extraction and quality assessment}

We used a data extraction tool developed in Google form based on a checklist provided in the Cochrane handbook for systematic review for intervention. The data extracted related to main study characteristics, including author, setting, type of randomised trial, intervention and control group details, and percentage of patients enrolled in intervention and control groups(see Table 1 at the end of manuscript for full characteristics of the studies). Meta-analysis data extracted included SBP/DBP changes from different non-pharmacological interventions (Additional file 4). 
The methodological quality of included studies was assessed using the Cochrane risk of bias tool Current version RoB 2, which include aspects of randomisation process; deviations from intended interventions; missing outcome data; measurement of the outcome; selection of the reported result, and overall bias (reported as Low, Some concerns or High) (Figure 2 ) [33]. Data extraction and quality assessment were conducted by two reviewers' (ON and SN), and the third author resolved discrepancies through discussions and consensus. The quality of evidence was assessed according to the domains specified in the grading of recommendation, assessment, development, and evaluation (GRADE) guidelines [34].

\section{Data synthesis and analysis}

The primary outcome of this study was to determine the effectiveness of interventions to enable hypertension medication adherence in Low-and Middle-Income Countries. Based on the nature of our research question, we synthesised the data by presenting changes in mean systolic blood pressure (SBP) and mean diastolic blood pressure (DBP). Systolic and diastolic blood pressure was analysed and calculated as mean difference (MD) and pooled to produce an overall random effect size between intervention and control groups. Heterogeneity among trials was conducted using the $\chi 2$ test at $95 \%$ confidence interval and $\mathrm{I}^{2}$ statistic value. Forest and funnel plots were presented to show the results for the primary outcome

The secondary outcome aim was to determine hypertension medication adherence between intervention and control groups. We synthesized the data descriptively by showing the proportion of patients with medication adherence between intervention and control groups and effect sizes for medication adherence between the two groups. Medication adherence indicators synthesized include quality of life, and knowledge, beliefs, and retention in clinical care, number of hospitalisations, and cost-effectiveness of interventions. We adopted the definitions used by individual studies for anti-hypertension treatment and adequate control of blood pressure. [35].

Data was captured in Microsoft Excel and analysed in MetaXL version 5.3 (EpiGear International, Sunrise Beach, and Queenland, Australia).

\section{Results}

\section{Literature search and study characteristics}

The initial database search found 162906 potentially eligible studies, of which 161991 were excluded during title screening. Following title screening, 915 met eligibility criteria and were included in full title screening yielding 14 definitive studies and considered for meta-analysis (see Fig. 1 for the whole screening process). The inter-rater reliability score for full-article screening showed $61.34 \%$ agreement versus $92.00 \%$ expected by chance which constitutes a moderate agreement between the screeners (Kappa statistic $=0.09$ and $p$-value $<0.05$ ). In addition, McNemar's chisquare statistic suggests that there is no statistically significant difference in the proportions of yes/no answers by reviewers with a p-value $>0.05$ (Additional file 3).

All studies included and considered for meta-analysis are from LMICs conducted between 2005-2020 among patients diagnosed with hypertension ranging from 18 to 75 years. Additionally, most studies included parallel randomised controlled trials ( $\mathrm{n}=13$ ) except one study, a 3arm randomised trial conducted in a low resource setting in Cape-Town, South Africa. Studies recruited patients mostly from rural settings and low resource settings $(n=7)$, and five were conducted from government hospitals, including a community pharmacy $(n=1)$. The main reason for exclusion was non-randomised trials $(n=8)$, not LMIC's $=14$; evaluated other chronic diseases apart from hypertension $(n=23)$ nonpharmacological $(n=5)$ and the rest were other reasons with studies which included older patients $>75$ years and unclear methodology and outcome $(n=36)$. All studies included were published in English. Included articles all evaluated Educational intervention towards patients, however $(7 / 14)$ articles evaluated more than one intervention of which it was either Educational intervention directed towards the health professional(2/14), Appointment reminder systems/models (7/14), or Organisational interventions (2/14). Appointment reminder systems encompassed principles of reminding patients when medicines were ready for collection or about scheduled clinic appointments information (2), organizational intervention aimed at delivery care- home BP monitoring and audit (2). Models on appointment reminder systems-reminder (3) box on taking medication.

The primary care providers were medical and nursing staff, community pharmacists and health workers, family support. Community interventions were delivered in community hospitals, community centres, or patients' homes (see Table 1).

\section{Quality of included studies}

Eleven (11) studies were graded to be Low risk, and three as having some concerns. All studies described randomisation methods; however, among the studies with some concerns, two had issues with the randomisation process where allocation sequence and concealment of participants enrolled and assigned to intervention was not indicated. The article with concerns of outcome measurement did not indicate whether the outcome assessment would have been influenced by the intervention received. The rest of the studies did not indicate any concerns with 
deviations from intended interventions, missing outcome data, issues with measurement of the outcome, and selection of the reported results (Fig. 2). Overall, the GRADE quality of evidence was moderate (Additional file 10).

\section{Effects of interventions}

\section{Primary outcomes (Meta-analysis results)}

Data pooled from all 14 studies showed heterogeneity across studies for systolic and diastolic blood pressure. Random effects of meta-analysis results show that systolic blood pressure was reduced by $-7.61(-10.47,-4.74)$, with four exceptions where systolic blood pressure was slightly lower in the intervention group. Heterogeneity across studies was statistically significant $(P=92 \%, \mathrm{P}=0.00)($ Fig. 3$)$. The pooled mean difference for diastolic blood pressure was $-3.48(-5.52,-43)$. Heterogeneity for DBP was statistically significant $P=89 \%, P=0.00)($ Fig. 4$)$. When we excluded two studies (Alhalaiqa, 2012 and Mirniam, 2019) SBP random effect was - 4.74 (95\% Cl:-6.07 to -3.47) and I² = 57\%. (Fig. 5) and DBP (-4.56-1.27) and $\mathrm{I}^{2}=78 \%$ (Fig. 6). Additional results showing funnel plots are included in the supplementary file material (Additional file 5-8).

\section{Secondary outcome}

\section{Proportion (\%) of patients with controlled BP (BP < 140/90mmHg}

Secondary outcome results indicating BP adherence outcome measures are presented as the proportion(\%) of controlled hypertensive patients with corresponding effect differences between intervention and control group through OR (95\% confidence interval). Additional secondary outcomes synthesised include quality of life, level of hypertension knowledge, beliefs on hypertension, retention to care, and the number of hospitalisations (Additional file 9). Out of 14 articles presented in this paper, 12 have shown a significant proportion of patients with controlled blood pressure $(\mathrm{BP}<140 / 90 \mathrm{mmHG})$.

\section{Other secondary outcome results}

In addition to the proportion of controlled hypertension reported from all 14 studies, a total number of BP medication adherence indicators from the included studies were synthesized as follows: articles that evaluated the quality of life(7); level of hypertension knowledge (2); beliefs on hypertension (2), retention to care (2); and the number of hospitalisations (2). Some studies reported more than one indicator. Results reporting on the quality of life display better overall health status in the intervention group(s) than those in the control group, similarly, with knowledge and beliefs. An increase in the knowledge level in the intervention groups was reported to modify patients' beliefs about medicines positively. Beliefs about medication in the intervention group have moved away from the view that medications are intrinsically harmful, towards one that recognises the benefits of medication. Retention in care, as well as hospital admissions, also improved. There was no significant difference in mean health care costs per patient between groups.

\section{Discussion}

Our systematic review findings reveal that Non-pharmacological interventions are effective in controlling blood pressure. We included studies from the following LMICs: Jordan, South Africa low resource settings, Turkey, India, Argentina, Bangladesh, Pakistan, Sri Lanka, Iran-Isfahan, Pakistan, China, and South Korea. We observed a statistically significant reduction in SBP and DBP .among the following interventions: Educational intervention towards patients, Educational intervention directed towards the health professional, Appointment reminder systems/models, and Organisational interventions. Educational interventions directed to the patient and health professional and Organisational interventions showed the high-moderate quality of evidence. These interventions can be pilot tested in LMIC's to establish suitable country specific BP strategies in anticipation to help meet Sustainable Development Goal (SDG) target 3.4 by reducing premature mortality from non-communicable diseases (NCDs) by a third by 2030. When we restricted analysis (12/14 studies), effects remained significant with low heterogeneity for SBP and DBP. Secondary outcomes, including quality of life, level of hypertension knowledge, beliefs on hypertension, retention to care, and the number of hospitalisations, showed a significant controlled blood pressure (BP $<140 / 90 \mathrm{mmHG}$ ). The aforementioned secondary outcomes are well outlined in the WHO model of hypertension medication adherence as contributing factors of BP medication adherence.

We believe that this is the first study to estimate aggregate BP effects of randomised controlled trials conducted in LMICs only. Studies included in this systematic review were conducted between 2005-2020 from low resource settings providing recent evidence on the effectiveness of BP interventions and medication adherence. The variability in heterogeneity can be observed when two studies (Alhalaiqa, 2012 and Mirniam) are excluded showing a significant reduction in SBP and DBP (Fig. 5 \&6)). These studies had the weakest effect in the intervention groups, which could have been caused by high heterogeneity in random-effect analysis. Overall, we attribute heterogeneity across studies to different study periods, sample sizes, and pooling of multi-component interventions between studies. Though our findings had moderate evidence on average primarily because of inconsistency and publication bias, heterogeneity was expected because it is common in behavioral research [36]. Similar results on heterogeneity have been reported in several studies in High-income countries that evaluated the effectiveness of BP interventions [26, 27]. Considering the current burden on hypertension in LMICs, our results have heightened the need for scaling up interventions to improve hypertension outcomes and meet global SDG in achieving universal health coverage in LMICs [37].

Page 5/21 
Meta-analysis studies on the effectiveness of BP interventions have been conducted in developed countries [26, 27]. Interventions for hypertension show a more significant effect when administered in combination[36]. In agreement with significant effects of BP interventions when administered in combination is a Cochrane systematic review of 72 randomised trial studies which stated that educational interventions alone were unlikely to be effective[20]. Authors such as Anderson LJ et al. (2020) and Ampofo AG (2020) have stated that education interventions and reminders, including regular follow-ups, were found to be effective at improving patient adherence [38, 39]. Health care workers play an essential role in making sure that these interventions are effective. Results from our study have shown a significant controlled blood pressure among Educational interventions directed to the patient-led by health care workers, especially pharmacists or community health care workers. According to European and Canadian guidelines, Pharmacists should be the standard care of hypertension as they are valuable in team-based care (TBC) $[40,41]$. The quality of our study findings was moderate on average, showing the reliability of our results. High-quality evidence was reported in a meta-analysis that evaluated non-pharmacological interventions, which concluded that Dietary Approach to Stop Hypertension (DASH) could be the most effective in hypertension management [27]. The high-quality evidence reported from DASH intervention could have been the result of evaluating more than 20 interventions from both High income and low-income countries included. The geographical settings of HIC and LMICs might have had an influence as well, in comparison to our study, which only focused on LMICs.

Our central findings that non-pharmacological interventions effectively control hypertension could positively impact non-adherence, subsequently reducing CVD's. Patients can get a better understand on hypertension management, which will eventually influence their awareness and behaviour towards BP medication adherence. More so, help clinicians make better decisions in clinical practice. The focus of this review was on RCT, which is the focused gold standard for evidence of the effectiveness of health [42]. In addition to the pooled change in systolic and diastolic blood pressure, the association between intervention and control group warrants health care workers to consider non-pharmacological interventions.

Hypertension management interventions are essential for achieving the global target of a $25 \%$ relative reduction in the risk of premature mortality from NCDs by 2025 and the SDG target of one-third reductions in premature deaths from NCDs by 2030. Thus, looking at our findings, nonpharmacological interventions for hypertension adherence could avoid over half of CVD events and complications in LMICs. Future research should focus more on evaluating the feasibility of BP non-pharmacological interventions in a specific LMIC setting. Specific LMIC interventions may enable the development of public policy measures required to establish, improve and upgrade community health services to cope with the increasing burden of chronic diseases [43]. More so, helping to identify the optimal and effective way to organise and deliver care to hypertensive patients in LMIC's $[19,20]$

\section{Conclusion}

Our study findings conclude that non-pharmacological interventions are effective. Educational interventions directed to the patient and health professional and Organisational interventions could be the most effective in managing hypertension. There is compelling evidence that multicomponent interventions delivered by pharmacists or health workers may be the most effective in hypertension management. The present and already stated interventions also positively affect outcomes of BP adherence which include quality of life, level of hypertension knowledge, beliefs, retention to care and number of hospitalisations.. Investigation of the feasibility of this evidence at a country level is necessary for LMIC to provide more reliable and effective interventions covering the country-specific needs having considered her health care system. A multi-component intervention involving patients, health professionals, and the health care system can be considered for future LMICs. Further well-designed randomised trials with larger sample sizes are encouraged to help policymakers make well-informed decisions on hypertension management.

\section{Abbreviations}

CVD: Cardio Vascular Diseases

LMICs: low- and Middle-Income Countries

HICs: Higher Income Countries

SBP/DBP: Systolic Blood Pressure/Diastolic Blood Pressure

WHO: World Health Organisation

NCDs: Non Communicable Diseases

BP: Blood Pressure

CHD: Coronary Heart Disease

SDG: Sustainable Development Goals RCT: Randomised Controlled Trials

GRADE: Grading Of Recommendation, Assessment, Development, and Evaluation 
TBC: Team-Based Care

DASH: Dietary Approach to Stop Hypertension

UKZN: University of KwaZulu-Natal

\section{Declarations}

\section{Acknowledgments}

The authors would like to thank the University of KwaZulu-Natal (UKZN) for providing the platform to set up and conduct this research study.

\section{Funding}

There was no funding source for this study. All authors had full access to all the data included in the study, and the corresponding author had final responsibility for the decision to submit for publication.

\section{Availability of data and materials}

All data reported and analysed in this paper was only from the published literature; hence most of the data and study materials are available in the public domain. Other datasets generated and analysed are available in the article and appendix.

\section{Authors' contributions}

The study has been conceptualized and designed by ON, BS and TPM-T. The initial draft of the study has been prepared by ON and PN, SN contributed to the abstract screening and full title screening. ON, BS, SJ-N and TPM-T contributed to data analysis. All authors critically reviewed the draft. All authors approved the final version of the manuscript.

\section{Ethics approval and consent to participate}

Not applicable

The were no human participants

\section{Consent for publication}

Not applicable

\section{Declaration of interest}

We declare no interest

\section{References}

1. Lim SS, Vos T, Flaxman AD, Danaei G, Shibuya K, Adair-Rohani H, et al. A comparative risk assessment of burden of disease and injury attributable to 67 risk factors and risk factor clusters in 21 regions, 1990-2010: a systematic analysis for the Global Burden of Disease Study 2010. Lancet. 2012;380(9859):2224-60.

2. Castellano JM, Bueno H, Fuster V. The cardiovascular polypill: clinical data and ongoing studies. Int J Cardiol. 2015;201:8-14.

3. Anand TN, Joseph LM, Geetha AV, Prabhakaran D, Jeemon P. Task sharing with non-physician health-care workers for management of blood pressure in low-income and middle-income countries: a systematic review and meta-analysis. The Lancet Global Health. 2019;7(6):e761-e71.

4. Dorje T, Zhao G, Tso K, Wang J, Chen Y, Tsokey L, et al. Smartphone and social media-based cardiac rehabilitation and secondary prevention in China (SMART-CR/SP): a parallel-group, single-blind, randomised controlled trial. The Lancet Digital Health. 2019;1(7):e363-e74.

5. WHO. Cardiovascular diseases 2017 [Available from: https://www.who.int/news-room/fact-sheets/detail/cardiovascular-diseases-(cvds).

6. Mills KT, Rubinstein A, Irazola V, Chen J, Beratarrechea A, Poggio R, et al. Comprehensive approach for hypertension control in low-income populations: rationale and study design for the hypertension control program in Argentina. Am J Med Sci. 2014;348(2):139-45.

7. <WEF_Harvard_HE_GlobalEconomicBurdenNonCommunicableDiseases_2011.pdf\&gt.

8. Musini VM, Gueyffier F, Puil L, Salzwedel DM, Wright JM. Pharmacotherapy for hypertension in adults aged 18 to 59 years. Cochrane Database Syst Rev. 2017;8:CD008276.

9. Gebru KKBABKHB. Adherence to Diabetes Self-Management Practices among Type li Diabetic Patients in Ethiopia; A Cross Sectional Study 2013. 
10. Ramanath K, Balaji D, Nagakishore C, Kumar SM, Bhanuprakash M. A study on impact of clinical pharmacist interventions on medication adherence and quality of life in rural hypertensive patients. J Young Pharm. 2012;4(2):95-100.

11. Waleed M, Sweileh SHZ. influence of patients disease knowladge and beliefs about medicines on medication adherence, findings from a cross sectional survey among patients with type 2 diabetes mellitus in palestine. 2014.

12. MoHSS. The Namibia Demographic and Health Survey In: Services, TNMoHaS, editors. Windhoek: Namibia; 2013. p. 530.

13. Kaputjaza DM. An epidemiological investigation of risk factors for hypertension in Windhoek. Khomas Region [Masters]: University of Namibia; 2017.

14. WHO. Global action plan for the prevention and control of noncommunicable diseases 2013-2020. WHO,Geneva2013. p. 55.

15. Burnier M, Egan BM. Adherence in Hypertension. Circ Res. 2019;124(7):1124-40.

16. Neupane D, McLachlan CS, Mishra SR, Olsen MH, Perry HB, Karki A, et al. Effectiveness of a lifestyle intervention led by female community health volunteers versus usual care in blood pressure reduction (COBIN): an open-label, cluster-randomised trial. The Lancet Global Health. 2018;6(1):e66-73.

17. Nashilongo MM, Singu B, Kalemeera F, Mubita M, Naikaku E, Baker A, et al. Assessing Adherence to Antihypertensive Therapy in Primary Health Care in Namibia: Findings and Implications. Cardiovasc Drugs Ther. 2017;31(5-6):565-78.

18. Awwad O, Akour A, Al-Muhaissen S, Morisky D. The influence of patients' knowledge on adherence to their chronic medications: a crosssectional study in Jordan. Int J Clin Pharm. 2015;37(3):504-10.

19. Schroeder K, Fahey T, Ebrahim S. Interventions for improving adherence to treatment in patients with high blood pressure in ambulatory settings. Cochrane Database Syst Rev. 2004(2):CD004804.

20. Glynn LG, Murphy AW, Smith SM, Schroeder K, Fahey T. Interventions used to improve control of blood pressure in patients with hypertension. Cochrane Database Syst Rev. 2010(3):Cd005182.

21. Gwadry-Sridhar FH, Manias E, Lal L, Salas M, Hughes DA, Ratzki-Leewing A, et al. Impact of Interventions on Medication Adherence and Blood Pressure Control in Patients with Essential Hypertension: A Systematic Review by the ISPOR Medication Adherence and Persistence Special Interest Group. Value in Health. 2013;16(5):863-71.

22. Ribeiro CD, Resqueti VR, Lima I, Dias FA, Glynn L, Fregonezi GA. Educational interventions for improving control of blood pressure in patients with hypertension: a systematic review protocol. BMJ Open. 2015;5(3):e006583.

23. Antonakoudis G, Poulimenos L, Kifnidis K, Zouras C, Antonakoudis H. Blood pressure control and cardiovascular risk reduction. Hippokratia. 2007;11(3):114-9.

24. <WHO. 2003 theories.pdf\&gt.

25. Alsolami FJA. Factors Affecting Antihypertensive Medications Adherence among Hypertensive Patients Attending a General Hospital in Jeddah City [Doctor of philosophy]. Saudi Arabia: Qeensland University of Technology; 2016.

26. Walsh J, McDonald KM, Shojania KG, Sundaram V, Nayak S, Davies S, et al. Closing the Quality Gap: A Critical Analysis of Quality Improvement Strategies. Vol. 3: Hypertension Care; 2005.

27. Fu J, Liu Y, Zhang L, Zhou L, Li D, Quan H, et al. Nonpharmacologic Interventions for Reducing Blood Pressure in Adults With Prehypertension to Established Hypertension. J Am Heart Assoc. 2020;9(19):e016804.

28. Dzudie A, Rayner B, Ojji D, Schutte AE, Twagirumukiza M, Damasceno A, et al. Roadmap to achieve $25 \%$ hypertension control in Africa by 2025. Cardiovasc J Afr. 2017;28(4):262-72.

29. Checkley W, Ghannem H, Irazola V, Kimaiyo S, Levitt NS, Miranda JJ, et al. Management of NCD in low- and middle-income countries. Global heart. 2014;9(4):431-43.

30. Whelton Paul K, Carey Robert M, Aronow Wilbert S, Casey Donald E, Collins Karen J, Dennison Himmelfarb C, et al 2017 ACC/AHA/AAPA/ABC/ACPM/AGS/APhA/ASH/ASPC/NMA/PCNA Guideline for the Prevention, Detection, Evaluation, and Management of High Blood Pressure in Adults. Journal of the American College of Cardiology. 2018;71(19):e127-e248.

31. Systematic Reviews. CRD`s guidedance for undertaking reviews in health care. Centre for Reviews and Dissemination; 2009.

32. Moher D, Liberati A, Tetzlaff J, Altman DG, Group atP. Preferred Reporting Items for Systematic Reviews and Meta-Analyses: The PRISMA Statement. Ann Intern Med. 2009;151(4):264-9.

33. Sterne JACSJ, Page MJ, Elbers RG, Blencowe NS, Boutron I, Cates CJ, Cheng H-Y, Corbett MS, Eldridge SM, Hernán MA, Hopewell S, Hróbjartsson A, Junqueira DR, Jüni P, Kirkham JJ, Lasserson T, Li T, McAleenan A, Reeves BC, Shepperd S, Shrier I, Stewart LA, Tilling K, White IR, Whiting PF, Higgins JPT. RoB 2: a revised tool for assessing risk of bias in randomised trials. 366: 14898BMJ 2019.

34. GRADE handbook for grading quality of evidence and strength of recommendations. Updated October 2013. The GRADE Working Group. Schünemann H BJ, Guyatt G, Oxman A, editors2013.

35. <cochrane-handbook-for-systematic-reviews-of-interventions.pdf>. 
36. Conn VS, Ruppar TM, Chase J-AD, Enriquez M, Cooper PS. Interventions to Improve Medication Adherence in Hypertensive Patients: Systematic Review and Meta-analysis. Curr Hypertens Rep. 2015;17(12):94-.

37. World Health 0 . Health workforce requirements for universal health coverage and the Sustainable Development Goals. (Human Resources for Health Observer, 17). Geneva: World Health Organization; 20162016.

38. Anderson LJ, Nuckols TK, Coles C, Le MM, Schnipper JL, Shane R, et al. A systematic overview of systematic reviews evaluating medication adherence interventions. American Journal of Health-System Pharmacy. 2020;77(2):138-47.

39. Ampofo AG, Khan E, Ibitoye MB. Understanding the role of educational interventions on medication adherence in hypertension: A systematic review and meta-analysis. Heart \& Lung: The Journal Of Critical Care; 2020.

40. Anker D, Tsuyuki RT, Paradis G, Chiolero A, Santschi V. Pharmacists to improve hypertension management: Guideline concordance from North America to Europe. Can Pharm J (Ott). 2019;152(3):180-5.

41. Carter BL, Bosworth HB, Green BB. The hypertension team: the role of the pharmacist, nurse, and teamwork in hypertension therapy. J Clin Hypertens (Greenwich). 2012;14(1):51-65.

42. Barton S. Which clinical studies provide the best evidence? BMJ. 2000;321(7256):255.

43. Lu Z, Cao S, Chai Y, Liang Y, Bachmann M, Suhrcke M, et al. Effectiveness of interventions for hypertension care in the community-a metaanalysis of controlled studies in China. BMC Health Serv Res. 2012;12:216-

\section{Tables}


Table 1

Characteristics of included studies

\begin{tabular}{|c|c|c|c|c|c|c|c|c|}
\hline \multirow{2}{*}{$\begin{array}{l}\text { Author, } \\
\text { Publication } \\
\text { Year }\end{array}$} & \multirow{2}{*}{$\begin{array}{l}\text { Country, } \\
\text { Geographical } \\
\text { Setting }\end{array}$} & \multirow{2}{*}{$\begin{array}{l}\text { Type of RCT \& } \\
\text { Intervention } \\
\text { type, Follow up } \\
\text { period(months) }\end{array}$} & \multicolumn{3}{|l|}{ Intervention Group } & \multicolumn{3}{|l|}{ Control Group } \\
\hline & & & $\begin{array}{l}\text { Population Details, Age } \\
\text { (y) }\end{array}$ & $\begin{array}{l}\text { Sample } \\
\text { Size, } \\
\text { Gender }\end{array}$ & & $\begin{array}{l}\text { Population } \\
\text { Details, Age (y) }\end{array}$ & $\begin{array}{l}\text { Sam } \\
\text { Genc }\end{array}$ & Size, \\
\hline Alhalaiqa,2012 & $\begin{array}{l}\text { Jordan, } 3 \\
\text { government-run } \\
\text { hospitals }\end{array}$ & $\begin{array}{l}\text { Parallel group } \\
\text { randomised } \\
\text { trial } \\
\text { Educational } \\
\text { intervention } \\
\text { directed to the } \\
\text { patient- } \\
\text { adherence } \\
\text { therapy classes; } \\
3 \text { months }\end{array}$ & $\begin{array}{l}\text { BP patients in the } \\
\text { intervention group } \\
\text { received Adherence } \\
\text { Therapy (AT) in } \\
\text { addition to Treatment } \\
\text { As Usual (TAU). AT } \\
\text { included seven one-to- } \\
\text { one sessions of AT } \\
\text { lasting } 20 \text { min over } 7 \\
\text { weeks.AT } \\
\text { sessions were delivered } \\
\text { in the hospital } \\
\text { outpatient by trained } \\
\text { Field Assistants } \\
\text { clinics ( } 25 \% \text { of all } \\
\text { sessions) or at the } \\
\text { patient's } \\
\text { home (75\% of all } \\
\text { sessions) depending } \\
\text { on the patient } \\
\text { preference, } \geq 18 \text { years }\end{array}$ & 68 & $\begin{array}{l}M= \\
37 \% \\
F=63 \%\end{array}$ & $\begin{array}{l}\text { BP patients in } \\
\text { the control } \\
\text { group received } \\
\text { TAU, which } \\
\text { consisted of } \\
\text { monthly } \\
\text { outpatient } \\
\text { clinics where } \\
\text { BP was } \\
\text { measured, } \\
\text { medication } \\
\text { reviewed, } \\
\text { laboratory } \\
\text { investigations, } \\
\text { and other care } \\
\text { was delivered } \\
\text { depending on } \\
\text { individual } \\
\text { needs. } \\
\text { Consisted of a } \\
\text { clinician-led } \\
\text { team of } \\
\text { medical and } \\
\text { nursing staff } \\
\text { based in the } \\
\text { outpatient } \\
\text { clinic, } \geq 18 \\
\text { years }\end{array}$ & 68 & $\begin{array}{l}M= \\
56 \% \\
F= \\
44 \%\end{array}$ \\
\hline Bobrow,2016(A) & $\begin{array}{l}\text { South Africa - } \\
\text { Cape town, low } \\
\text { resource setting }\end{array}$ & $\begin{array}{l}\text { - 3-arm } \\
\text { randomised } \\
\text { trial(Bobrow A \& } \\
\text { B } \\
\text { Educational } \\
\text { intervention } \\
\text { directed to the } \\
\text { patients- written } \\
\text { information } \\
\text { about } \\
\text { hypertension } \\
\text { and healthy } \\
\text { living, } \\
\text { motivation on } \\
\text { collecting and } \\
\text { taking medicine } \\
\text { Appointment } \\
\text { reminder } \\
\text { system- when } \\
\text { medicines were } \\
\text { ready for } \\
\text { collection or } \\
\text { about } \\
\text { scheduled clinic } \\
\text { appointments } \\
\text { information } \\
\text { 12 months }\end{array}$ & $\begin{array}{l}\text { Informational SMS } \\
\text { texting: All participants } \\
\text { received written } \\
\text { information about } \\
\text { hypertension and } \\
\text { healthy living and } \\
\text { continued to receive } \\
\text { care from the clinic. } \\
\text { Personalized SMS text } \\
\text { messages were sent to } \\
\text { information-only. } \\
\text { Adherence support } \\
\text { groups were sent } \\
\text { messages to motivate } \\
\text { collecting and taking } \\
\text { medicines and } \\
\text { educating about } \\
\text { hypertension and its } \\
\text { treatment. Additional } \\
\text { reminders were sent } \\
\text { when medicines were } \\
\text { ready for collection or } \\
\text { about scheduled clinic } \\
\text { appointments. } \\
, \geq 21 \text { years }\end{array}$ & 457 & $\begin{array}{l}M= \\
28 \% \\
F=72 \%\end{array}$ & $\begin{array}{l}\text { Usual care: All } \\
\text { participants } \\
\text { received written } \\
\text { information } \\
\text { about } \\
\text { hypertension } \\
\text { and healthy } \\
\text { living and } \\
\text { continued to } \\
\text { receive care } \\
\text { from the clinic, } \\
\geq 21 \text { years }\end{array}$ & 457 & $\begin{array}{l}M= \\
28 \% \\
F= \\
72 \%\end{array}$ \\
\hline
\end{tabular}




\begin{tabular}{|c|c|c|c|c|c|c|c|c|}
\hline \multirow{2}{*}{$\begin{array}{l}\text { Author, } \\
\text { Publication } \\
\text { Year }\end{array}$} & \multirow{2}{*}{$\begin{array}{l}\text { Country, } \\
\text { Geographical } \\
\text { Setting }\end{array}$} & \multirow{2}{*}{$\begin{array}{l}\text { Type of RCT \& } \\
\text { Intervention } \\
\text { type, Follow up } \\
\text { period(months) }\end{array}$} & \multicolumn{3}{|l|}{ Intervention Group } & \multicolumn{3}{|l|}{ Control Group } \\
\hline & & & $\begin{array}{l}\text { Population Details, Age } \\
\text { (v) }\end{array}$ & $\begin{array}{l}\text { Sample } \\
\text { Size, } \\
\text { Gender }\end{array}$ & & $\begin{array}{l}\text { Population } \\
\text { Details, Age (y) }\end{array}$ & $\begin{array}{l}\text { Sam } \\
\text { Gen }\end{array}$ & e Size \\
\hline Bobrow,2016(B) & $\begin{array}{l}\text { South Africa- } \\
\text { Cape town, low } \\
\text { resource setting }\end{array}$ & $\begin{array}{l}\text { Educational } \\
\text { intervention } \\
\text { directed to the } \\
\text { patients- written } \\
\text { information } \\
\text { about } \\
\text { hypertension } \\
\text { and healthy } \\
\text { living, } \\
\text { interactive texts } \\
\text { on healthy } \\
\text { living, } \\
\text { motivation on } \\
\text { collecting and } \\
\text { taking medicine } \\
\text { Appointment } \\
\text { reminder } \\
\text { system- when } \\
\text { medicines were } \\
\text { ready for } \\
\text { collection or } \\
\text { about } \\
\text { scheduled clinic } \\
\text { appointments } \\
\text { information } \\
12 \text { months }\end{array}$ & $\begin{array}{l}\text { Interactive SMS } \\
\text { texting: All BP } \\
\text { participants received } \\
\text { written information } \\
\text { about hypertension } \\
\text { and healthy living and } \\
\text { continued to receive } \\
\text { care from the clinic. } \\
\text { Personalized SMS text } \\
\text { messages were sent to } \\
\text { interactive message } \\
\text { group participants at } \\
\text { weekly intervals. } \\
\text { Messages were sent to } \\
\text { motivate collecting and } \\
\text { taking medicines and } \\
\text { provide education } \\
\text { about hypertension } \\
\text { and its treatment. } \\
\text { Additional reminders } \\
\text { were sent when } \\
\text { medicines were ready } \\
\text { for collection or about } \\
\text { scheduled clinic } \\
\text { appointments. } \\
\text { Participants allocated } \\
\text { to the interactive } \\
\text { adherence support } \\
\text { received the same } \\
\text { messages as the } \\
\text { information-only group } \\
\text { but could also respond } \\
\text { to selected messages } \\
\text { using free-to-user } \\
\text { "Please-Call-Me" } \\
\text { requests, } \geq 21 \text { years }\end{array}$ & 458 & $\begin{array}{l}M= \\
28 \% \\
F=72 \%\end{array}$ & $\begin{array}{l}\text { Usual care: All } \\
\text { BP participants } \\
\text { received written } \\
\text { information } \\
\text { about } \\
\text { hypertension } \\
\text { and healthy } \\
\text { living and } \\
\text { continued to } \\
\text { receive care } \\
\text { from the clinic, } \\
\geq 21 \text { years }\end{array}$ & 457 & $\begin{array}{l}M= \\
28 \% \\
F= \\
72 \%\end{array}$ \\
\hline
\end{tabular}




\begin{tabular}{|c|c|c|c|c|c|c|c|c|}
\hline \multirow{2}{*}{$\begin{array}{l}\text { Author, } \\
\text { Publication } \\
\text { Year }\end{array}$} & \multirow{2}{*}{$\begin{array}{l}\text { Country, } \\
\text { Geographical } \\
\text { Setting }\end{array}$} & \multirow{2}{*}{$\begin{array}{l}\text { Type of RCT \& } \\
\text { Intervention } \\
\text { type, Follow up } \\
\text { period(months) }\end{array}$} & \multicolumn{3}{|l|}{ Intervention Group } & \multicolumn{3}{|l|}{ Control Group } \\
\hline & & & $\begin{array}{l}\text { Population Details, Age } \\
\text { (y) }\end{array}$ & $\begin{array}{l}\text { Sample } \\
\text { Size, } \\
\text { Gender }\end{array}$ & & $\begin{array}{l}\text { Population } \\
\text { Details, Age (y) }\end{array}$ & $\begin{array}{l}\text { Sar } \\
\text { Ger }\end{array}$ & Size, \\
\hline Cakir,2006 & $\begin{array}{l}\text { Turkey, } \\
\text { University } \\
\text { hospital in } \\
\text { Istanbul }\end{array}$ & $\begin{array}{l}\text { - Parallel group } \\
\text { randomised } \\
\text { trial } \\
\text { Educational } \\
\text { intervention } \\
\text { directed to the } \\
\text { patient- } \\
\text { comprehensive } \\
\text { lifestyle } \\
\text { modification } \\
\text { including DASH } \\
\text { diet, weight } \\
\text { reduction, } \\
\text { sodium intake, } \\
\text { reducing } \\
\text { alcohol } \\
\text { consumption, } \\
\text { increasing } \\
\text { physical } \\
\text { exercise to a } \\
\text { moderate } \\
\text { degree, giving } \\
\text { up cigarette } \\
\text { smoking, and } \\
\text { learning stress } \\
\text { management. } \\
\text { Classes were } \\
\text { given by nurses } \\
\text { on how to } \\
\text { control } \\
\text { hypertension to } \\
\text { prevent heart } \\
\text { diseases and } \\
\text { stroke and } \\
\text { included core } \\
\text { knowledge and } \\
\text { information on } \\
\text { the behavioural } \\
\text { skills necessary } \\
\text { to manage } \\
\text { hypertension } \\
6 \text { months } \\
\text { inds }\end{array}$ & $\begin{array}{l}\text { BP patients } \\
\text { comprehensive lifestyle } \\
\text { modification including } \\
\text { DASH diet, reduce } \\
\text { weight, sodium intake, } \\
\text { reduce alcohol } \\
\text { consumption, increase } \\
\text { physical exercise to a } \\
\text { moderate degree, give } \\
\text { up cigarette smoking, } \\
\text { Moreover, to learn } \\
\text { stress management. } \\
\text { Classes were given by } \\
\text { nurses on how to } \\
\text { control hypertension to } \\
\text { prevent heart diseases } \\
\text { and stroke and } \\
\text { included core } \\
\text { knowledge and } \\
\text { information on the } \\
\text { behavioural skills } \\
\text { necessary to manage } \\
\text { hypertension }\end{array}$ & 30 & $\begin{array}{l}M= \\
47 \% \\
F=63 \%\end{array}$ & $\begin{array}{l}\text { BP patients } \\
\text { received usual } \\
\text { lifestyles, } \\
\text { including } \\
\text { dietary and } \\
\text { exercise habits, } \\
\text { for } 6 \text { months }\end{array}$ & 30 & $\begin{array}{l}M= \\
40 \% \\
F= \\
60 \%\end{array}$ \\
\hline Calvaho,2006 & $\begin{array}{l}\text { India-Mysore } \\
\text { city, Rural } \\
\text { community } \\
\text { pharmacies }\end{array}$ & $\begin{array}{l}\text { A parallel } \\
\text { randomised } \\
\text { controlled trial } \\
\text { Educational } \\
\text { intervention } \\
\text { directed to the } \\
\text { patient- } \\
\text { education on } \\
\text { BP, medication, } \\
\text { and lifestyle } \\
\text { modifications } \\
3 \text { months }\end{array}$ & $\begin{array}{l}\text { BP patients without } \\
\text { comorbidities were } \\
\text { provided with } \\
\text { education on BP, } \\
\text { medication, and } \\
\text { lifestyle modifications } \\
\text { by a community } \\
\text { pharmacist for } 3 \\
\text { months, } \geq 18 \text { years }\end{array}$ & 26 & $\begin{array}{l}M= \\
53.85 \% \\
F= \\
46.15 \%\end{array}$ & $\begin{array}{l}\text { BP patients } \\
\text { with or without } \\
\text { comorbidities } \\
\text { were provided } \\
\text { with basic } \\
\text { education on } \\
\text { the correct way } \\
\text { to take } \\
\text { medication for } \\
\text { three months, } \geq \\
18 \text { years }\end{array}$ & 21 & $\begin{array}{l}M= \\
38.1 \% \\
F= \\
61.9 \%\end{array}$ \\
\hline
\end{tabular}




\begin{tabular}{|c|c|c|c|c|c|c|c|c|}
\hline \multirow{2}{*}{$\begin{array}{l}\text { Author, } \\
\text { Publication } \\
\text { Year }\end{array}$} & \multirow{2}{*}{$\begin{array}{l}\text { Country, } \\
\text { Geographical } \\
\text { Setting }\end{array}$} & \multirow{2}{*}{$\begin{array}{l}\text { Type of RCT \& } \\
\text { Intervention } \\
\text { type, Follow up } \\
\text { period(months) }\end{array}$} & \multicolumn{3}{|l|}{ Intervention Group } & \multicolumn{3}{|l|}{ Control Group } \\
\hline & & & $\begin{array}{l}\text { Population Details, Age } \\
\text { (y) }\end{array}$ & $\begin{array}{l}\text { Sample } \\
\text { Size, } \\
\text { Gender }\end{array}$ & & $\begin{array}{l}\text { Population } \\
\text { Details, Age (y) }\end{array}$ & $\begin{array}{l}\text { Sam } \\
\text { Genc }\end{array}$ & Size, \\
\hline Delavar,2019 & $\begin{array}{l}\text { Iran-Tehran, } \\
\text { Fayyazbakhsh } \\
\text { public hospital }\end{array}$ & $\begin{array}{l}\text { Parallel group } \\
\text { randomised } \\
\text { trial } \\
\text { Educational } \\
\text { intervention } \\
\text { directed to the } \\
\text { patient- patients } \\
\text { received SME } \\
\text { tailored Patient } \\
\text { Health Literacy, } \\
\text { weekly face-to- } \\
\text { face sessions, } \\
\text { and telephone- } \\
\text { based } \\
\text { educational } \\
\text { sessions twice } \\
\text { weekly. Given } \\
\text { educational } \\
\text { materials } \\
1 \text { month }\end{array}$ & $\begin{array}{l}\text { Elderly primary BP } \\
\text { patients who received } \\
\text { SME tailored Patient } \\
\text { Health Literacy for } 3 \\
\text { months (HL) face to } \\
\text { face weekly sessions } \\
\text { and telephone-based } \\
\text { educational sessions } \\
\text { twice weekly. Given } \\
\text { educational materials } \\
\text { by } \\
\text { Four experts(one } \\
\text { critical care and three } \\
\text { health promotion } \\
\text { specialists) } \\
\text { Educational materials } \\
\text { were related to } \\
\text { hypertension definition } \\
\text { and its risk factors, } \\
\text { complications, } \\
\text { medications, } \\
\text { medication side } \\
\text { effects, medication } \\
\text { side effect } \\
\text { management, } \\
\text { medication adherence } \\
\text { importance, and the } \\
\text { importance of regular } \\
\text { medical visits for blood } \\
\text { pressure monitoring. } \\
\text { Because of } \\
\text { participants' old age } \\
\text { and their inadequate } \\
\text { HL, the teach-back } \\
\text { method was used to } \\
\text { provide educational } \\
\text { materials in both face- } \\
\text { to-face and telephone-- } \\
\text { based educational } \\
\text { sessions, } \geq 60 \text { years }\end{array}$ & 54 & $\begin{array}{l}M= \\
41.6 \% \\
F= \\
57.4 \%\end{array}$ & $\begin{array}{l}\text { Elderly primary } \\
\text { BP patients } \\
\text { who received } \\
\text { routine care } \\
\text { services, } \\
\text { including } \\
\text { routine medical } \\
\text { visits, medical } \\
\text { prescriptions, } \\
\text { and blood } \\
\text { pressure } \\
\text { management. } \\
, \geq 60 \text { years }\end{array}$ & 58 & $\begin{array}{l}M= \\
55.2 \% \\
F= \\
44.8 \%\end{array}$ \\
\hline $\mathrm{He}, 2017$ & $\begin{array}{l}\text { Argentina, poor } \\
\text { urban primary } \\
\text { health centres }\end{array}$ & $\begin{array}{l}\text { Parallel group } \\
\text { randomised } \\
\text { trial } \\
\text { Educational } \\
\text { intervention } \\
\text { directed to the } \\
\text { patient-health } \\
\text { coaching, } \\
\text { physical } \\
\text { education } \\
\text { Educational } \\
\text { intervention } \\
\text { directed to the } \\
\text { health } \\
\text { professionals- } \\
\text { physician } \\
\text { training } \\
\text { program,(online } \\
\text { and onsite } \\
\text { hypertension } \\
\text { management } \\
\text { organizational } \\
\text { intervention } \\
\text { aimed at } \\
\text { delivery care- } \\
\text { home BP } \\
\text { monitoring and } \\
\text { audit } \\
18 \text { months }\end{array}$ & $\begin{array}{l}\text { BP patients received an } \\
\text { 18-month multi- } \\
\text { component } \\
\text { intervention program } \\
\text { including a community } \\
\text { health worker-led } \\
\text { home-based } \\
\text { intervention (health } \\
\text { coaching and home BP } \\
\text { monitoring and audit), } \\
\text { physical education, BP } \\
\text { feedback, and weekly } \\
\text { text messaging, } \geq 21 \\
\text { years. }\end{array}$ & 743 & $\begin{array}{l}M= \\
47.4 \% \\
F= \\
52.6 \%\end{array}$ & $\begin{array}{l}\text { Neither } \\
\text { physicians } \\
\text { nor community } \\
\text { health workers } \\
\text { were trained to } \\
\text { conduct } \\
\text { study } \\
\text { interventions. } \\
\text { Additionally, } \\
\text { participants did } \\
\text { not receive } \\
\text { home visits, } \\
\text { home BP } \\
\text { monitors, or } \\
\text { text messages. } \\
\text { Participants } \\
\text { were } \\
\text { encouraged to } \\
\text { follow the } \\
\text { clinical visit } \\
\text { schedule } \\
\text { of the } \\
\text { Remediar + } \\
\text { Redes } \\
\text { Program, } \geq 21 \\
\text { years }\end{array}$ & 689 & $\begin{array}{l}M= \\
46.6 \% \\
F= \\
53.4 \%\end{array}$ \\
\hline
\end{tabular}




\begin{tabular}{|c|c|c|c|c|c|c|c|c|}
\hline \multirow{2}{*}{$\begin{array}{l}\text { Author, } \\
\text { Publication } \\
\text { Year }\end{array}$} & \multirow{2}{*}{$\begin{array}{l}\text { Country, } \\
\text { Geographical } \\
\text { Setting }\end{array}$} & \multirow{2}{*}{$\begin{array}{l}\text { Type of RCT \& } \\
\text { Intervention } \\
\text { type, Follow up } \\
\text { period(months) }\end{array}$} & \multicolumn{3}{|l|}{ Intervention Group } & \multicolumn{3}{|l|}{ Control Group } \\
\hline & & & $\begin{array}{l}\text { Population Details, Age } \\
\text { (y) }\end{array}$ & $\begin{array}{l}\text { Sample } \\
\text { Size, } \\
\text { Gender }\end{array}$ & & $\begin{array}{l}\text { Population } \\
\text { Details, Age (y) }\end{array}$ & $\begin{array}{l}\text { Samp } \\
\text { Gende }\end{array}$ & Size, \\
\hline Jafar,2020 & $\begin{array}{l}\text { Bangladesh, } \\
\text { Pakistan, and } \\
\text { Sri Lanka, rural } \\
\text { districts }\end{array}$ & $\begin{array}{l}\text { Parallel group } \\
\text { randomised } \\
\text { trial } \\
\text { Educational } \\
\text { intervention } \\
\text { directed to the } \\
\text { patient-home } \\
\text { education } \\
\text { Educational } \\
\text { intervention } \\
\text { directed at the } \\
\text { health } \\
\text { professional- } \\
\text { physician } \\
\text { training } \\
\text { program on } \\
\text { hypertension } \\
\text { management } \\
\text { Organizational } \\
\text { interventions } \\
\text { aimed at } \\
\text { delivery care- } \\
\text { Hypertension } \\
\text { triage reception } \\
\text { desk and } \\
\text { hypertension } \\
\text { care } \\
\text { coordinator at } \\
\text { the government } \\
\text { clinics } \\
24 \text { months }\end{array}$ & $\begin{array}{l}\text { BP patients received } 24 \\
\text { months of Multi- } \\
\text { component } \\
\text { intervention: blood- } \\
\text { pressure monitoring by } \\
\text { physicians and the use } \\
\text { of checklists to guide } \\
\text { monitoring and referral } \\
\text { to physicians. } \\
\text { Involvement of } \\
\text { Government } \\
\text { community health } \\
\text { workers to measure } \\
\text { blood pressure; home } \\
\text { health education } \\
\text { by government } \\
\text { community health } \\
\text { workers. Hypertension } \\
\text { triage reception desk } \\
\text { and hypertension } \\
\text { care coordinator at the } \\
\text { government clinics. } \\
\text {, } 240 y e a r s\end{array}$ & 1330 & $\begin{array}{l}M= \\
34.1 \% \\
F= \\
65.9 \%\end{array}$ & $\begin{array}{l}\text { BP patients } \\
\text { received } 24 \\
\text { months of } \\
\text { Usual care } \\
\text { consisted of } \\
\text { existing } \\
\text { services in the } \\
\text { community, } \\
\text { with routine } \\
\text { home visits by } \\
\text { community } \\
\text { health workers } \\
\text { for maternal } \\
\text { and child } \\
\text { care only. The } \\
\text { clinics did not } \\
\text { have } \\
\text { designated } \\
\text { triage reception } \\
\text { desks or care } \\
\text { coordinators } \\
\text { for } \\
\text { hypertension. } \\
\text {, } 40 \text { years }\end{array}$ & 1315 & $\begin{array}{l}M= \\
37.3 \% \\
F= \\
62.7 \%\end{array}$ \\
\hline Mirniam,2019 & $\begin{array}{l}\text { Iran-Isfahan, Al } \\
\text { Zahra hospital }\end{array}$ & $\begin{array}{l}\text { Parallel group } \\
\text { randomised } \\
\text { trial } \\
\text { Educational } \\
\text { intervention } \\
\text { directed to the } \\
\text { patient- } \\
\text { education on } \\
\text { consequences } \\
\text { of not taking } \\
\text { HTN } \\
\text { medication, } \\
\text { methods of } \\
\text { controlling the } \\
\text { disease via } \\
\text { appropriate } \\
\text { lifestyle } \\
\text { changes } \\
\text { Models on } \\
\text { appointment } \\
\text { reminder } \\
\text { systems- } \\
\text { reminder box on } \\
\text { taking } \\
\text { medication } \\
\text { through family } \\
\text { support } \\
3 \text { months }\end{array}$ & $\begin{array}{l}\text { BP patients who } \\
\text { received Multifaceted } \\
\text { interventions include } \\
\text { motivational interviews } \\
\text { and } 90 \text { minutes of } \\
\text { training sessions, a } \\
\text { drug reminder box, } \\
\text { family support, and } 4 \\
\text { phone call follow-ups. } \\
\text { The content of } \\
\text { the training sessions } \\
\text { consisted of the nature } \\
\text { and side effects of the } \\
\text { disease, the } \\
\text { consequences of not } \\
\text { taking HTN medication, } \\
\text { methods of controlling } \\
\text { the disease via } \\
\text { appropriate lifestyle } \\
\text { changes, and } \\
\text { etcetera, The content of } \\
\text { the phone calls } \\
\text { included question and } \\
\text { answer } \\
\text { sessions regarding the } \\
\text { reinforcement of the } \\
\text { content } \\
\text { of the training } \\
\text { sessions, techniques of } \\
\text { strengthening } \\
\text { family support, } \\
\text { utilization of the } \\
\text { medication } \\
\text { reminder box, and } \\
\text { answers to possible } \\
\text { problems of } \\
\text { the participants } \\
\geq 18 y e a r s\end{array}$ & 36 & $\begin{array}{l}\mathrm{M}= \\
47.2 \% \\
\mathrm{~F}= \\
52.8 \%\end{array}$ & $\begin{array}{l}\text { BP patients } \\
\text { who did not } \\
\text { receive } \\
\text { multifaceted } \\
\text { intervention, } \\
\text { only usual } \\
\text { traditional care, } \\
\geq 18 \text { years }\end{array}$ & 36 & $\begin{array}{l}M= \\
50.0 \% \\
F= \\
50.0 \%\end{array}$ \\
\hline
\end{tabular}




\begin{tabular}{|c|c|c|c|c|c|c|c|c|}
\hline \multirow{2}{*}{$\begin{array}{l}\text { Author, } \\
\text { Publication } \\
\text { Year }\end{array}$} & \multirow{2}{*}{$\begin{array}{l}\text { Country, } \\
\text { Geographical } \\
\text { Setting }\end{array}$} & \multirow{2}{*}{$\begin{array}{l}\text { Type of RCT \& } \\
\text { Intervention } \\
\text { type, Follow up } \\
\text { period(months) }\end{array}$} & \multicolumn{3}{|l|}{ Intervention Group } & \multicolumn{3}{|l|}{ Control Group } \\
\hline & & & $\begin{array}{l}\text { Population Details, Age } \\
\text { (y) }\end{array}$ & $\begin{array}{l}\text { Sample } \\
\text { Size, } \\
\text { Gender }\end{array}$ & & $\begin{array}{l}\text { Population } \\
\text { Details, Age (y) }\end{array}$ & $\begin{array}{l}\text { Sam } \\
\text { Genc }\end{array}$ & Size, \\
\hline Ramanath,2012 & $\begin{array}{l}\text { India - Medicine } \\
\text { department of } \\
\text { Adichnchanagiri } \\
\text { hospital and } \\
\text { research centre- } \\
\text { B G Nagara, } \\
\text { rural population }\end{array}$ & $\begin{array}{l}\text { Parallel group } \\
\text { randomised } \\
\text { trial } \\
\text { Educational } \\
\text { intervention } \\
\text { directed to the } \\
\text { patients -patient } \\
\text { counselling, } \\
\text { patient } \\
\text { information } \\
\text { leaflets (PILS) } \\
\text { Models on } \\
\text { appointment } \\
\text { reminder } \\
\text { systems- } \\
\text { frequent } \\
\text { telephonic } \\
\text { reminding } \\
7 \text { months }\end{array}$ & $\begin{array}{l}\text { Clinical pharmacist } \\
\text { intervention patient } \\
\text { counselling, patient } \\
\text { information leaflets } \\
\text { (PILS), and frequent } \\
\text { telephonic reminding. } \\
\text { patients were } \\
\text { counselled on various } \\
\text { aspects such as drugs, } \\
\text { lifestyle changes, and } \\
\text { their disease } \\
\text { management, } \geq 18 y e a r s\end{array}$ & 26 & $\begin{array}{l}M= \\
61.5 \% \\
F= \\
38.5 \%\end{array}$ & $\begin{array}{l}\text { Patients were } \\
\text { not provided } \\
\text { with any } \\
\text { counselling } \\
\text { and PILS at the } \\
\text { baseline and in } \\
\text { the first follow- } \\
\text { up. However, } \\
\text { They were } \\
\text { provided with } \\
\text { oral instruction } \\
\text { and PIL at the } \\
\text { end of the } \\
\text { second follow- } \\
\text { up. , } \geq 18 y e a r s\end{array}$ & 26 & $\begin{array}{l}M= \\
80.8 \% \\
F= \\
19.2 \%\end{array}$ \\
\hline Saleem,2015 & $\begin{array}{l}\text { Pakistan- } \\
\text { Northwest } \\
\text { Balochistan, } \\
\text { Cardiac units of } \\
\text { Sandeman } \\
\text { Provincial } \\
\text { Hospital (SPH) } \\
\text { and Bolan } \\
\text { Medical } \\
\text { Complex } \\
\text { Hospital } \\
\text { (BMCH) located } \\
\text { in Quetta }\end{array}$ & $\begin{array}{l}\text { Parallel group } \\
\text { randomised } \\
\text { trial } \\
\text { Educational } \\
\text { intervention } \\
\text { directed to the } \\
\text { patient- pocket- } \\
\text { sized } \\
\text { educational } \\
\text { book on } \\
\text { hypertension, } \\
\text { information } \\
\text { leaflets, and } \\
\text { medication } \\
\text { adherence } \\
\text { cards } \\
9 \text { months }\end{array}$ & $\begin{array}{l}\text { BP patients Who } \\
\text { received } \\
\text { pharmaceutical care, } \\
\text { consisting of follow-up } \\
\text { by the trained hospital } \\
\text { pharmacist during } 9 \\
\text { months. At each visit, } \\
\text { the hospital } \\
\text { pharmacist conducted } \\
\text { a thorough interview } \\
\text { with the patient, } \\
\text { identified } \\
\text { Problems leading to } \\
\text { poor medication } \\
\text { adherence and } \\
\text { provided patient } \\
\text { education. Patients in } \\
\text { the IG were also } \\
\text { provided with a pocket- } \\
\text { sized educational } \\
\text { book on hypertension, } \\
\text { information leaflets, } \\
\text { and medication } \\
\text { adherence cards (all in } \\
\text { Urdu) during the } \\
\text { counseling } \\
\text { process, } \geq 18 y e a r s\end{array}$ & 193 & $\begin{array}{l}M= \\
64.8 \% \\
F= \\
35.2 \%\end{array}$ & $\begin{array}{l}\text { BP patients } \\
\text { who were not } \\
\text { provided with } \\
\text { pharmaceutical } \\
\text { care, no } \\
\text { hospital } \\
\text { pharmacist } \\
\text { involvement. } \\
\text { Control } \\
\text { patients } \\
\text { received the } \\
\text { traditional } \\
\text { service } \\
\text { provided by the } \\
\text { hospitals } \\
\text { (receiving } \\
\text { prescription } \\
\text { orders, } \\
\text { counselling } \\
\text { about } \\
\text { medication } \\
\text { use, and } \\
\text { information } \\
\text { about follow- } \\
\text { up visits). } \\
\text {, } 18 y e a r s\end{array}$ & 192 & $\begin{array}{l}M= \\
72.9 \% \\
F= \\
27.1 \%\end{array}$ \\
\hline
\end{tabular}




\begin{tabular}{|c|c|c|c|c|c|c|c|c|}
\hline \multirow{2}{*}{$\begin{array}{l}\text { Author, } \\
\text { Publication } \\
\text { Year }\end{array}$} & \multirow{2}{*}{$\begin{array}{l}\text { Country, } \\
\text { Geographical } \\
\text { Setting }\end{array}$} & \multirow{2}{*}{$\begin{array}{l}\text { Type of RCT \& } \\
\text { Intervention } \\
\text { type, Follow up } \\
\text { period(months) }\end{array}$} & \multicolumn{3}{|l|}{ Intervention Group } & \multicolumn{3}{|l|}{ Control Group } \\
\hline & & & $\begin{array}{l}\text { Population Details, Age } \\
\text { (v) }\end{array}$ & $\begin{array}{l}\text { Sample } \\
\text { Size, } \\
\text { Gender }\end{array}$ & & $\begin{array}{l}\text { Population } \\
\text { Details, Age (y) }\end{array}$ & $\begin{array}{l}\text { Samp } \\
\text { Gend }\end{array}$ & Size, \\
\hline Zhai,2020 & $\begin{array}{l}\text { China-Xi'an city } \\
\text { Shaanxi } \\
\text { province, } 8 \\
\text { community } \\
\text { health care } \\
\text { centres (CHCs) }\end{array}$ & $\begin{array}{l}\text { Parallel group } \\
\text { randomised } \\
\text { trial } \\
\text { Educational } \\
\text { intervention } \\
\text { directed to the } \\
\text { patient- } \\
\text { personal } \\
\text { consultations } \\
\text { by trained } \\
\text { pharmacy } \\
\text { students on BP } \\
\text { medication } \\
\text { adherence } \\
\text { Models on } \\
\text { appointment } \\
\text { reminder } \\
\text { systems- SMS } \\
\text { text messages s } \\
\text { regarding } \\
\text { patients with } \\
\text { poor knowledge } \\
\text { on BP } \\
\text { adherence and } \\
\text { lifestyle } \\
\text { modification } \\
3 \text { months }\end{array}$ & $\begin{array}{l}\text { BP patients who } \\
\text { receive intervention for } \\
3 \text { months program } \\
\text { comprised } 2 \\
\text { components. Personal } \\
\text { consultations by } \\
\text { trained pharmacy } \\
\text { students. The second } \\
\text { component was SMS } \\
\text { text messages s } \\
\text { Regarding } \\
\text { patients with poor } \\
\text { knowledge were given } \\
\text { education on BP } \\
\text { adherence and lifestyle } \\
\text { modification } \\
, \geq 18 y e a r s\end{array}$ & 192 & $\begin{array}{l}M= \\
35.4 \% \\
F= \\
64.6 \%\end{array}$ & $\begin{array}{l}\text { BP patients } \\
\text { who received a } \\
\text { welcome SMS } \\
\text { text } \\
\text { message and } \\
\text { an end-of-trial } \\
\text { SMS text } \\
\text { message but } \\
\text { they did not } \\
\text { receive a } \\
\text { personal } \\
\text { consultation. } \\
, \geq 18 y e a r s\end{array}$ & 192 & $\begin{array}{l}M= \\
35.4 \% \\
F= \\
64.6 \%\end{array}$ \\
\hline Park,2011 & South Korea & $\begin{array}{l}\text { Parallel group } \\
\text { randomised } \\
\text { trial } \\
\text { Educational } \\
\text { intervention } \\
\text { directed to the } \\
\text { patient- HAHA } \\
\text { program (health } \\
\text { education, } \\
\text { individual } \\
\text { counselling, } \\
\text { and tailored } \\
\text { exercise } \\
\text { program } \\
\text { delivered by } \\
\text { trained nurses } \\
\text { and exercise } \\
\text { program for } 12 \\
\text { weeks) } \\
3 \text { months }\end{array}$ & $\begin{array}{l}\text { BP patients who were } \\
\text { given HAHA program } \\
\text { (education counselling } \\
\text { delivered by trained } \\
\text { nurses and exercise } \\
\text { program for } 12 \text { weeks) } \\
\geq 65 \text { years }\end{array}$ & 18 & $\begin{array}{l}M= \\
33.3 \% \\
F= \\
66.7 \%\end{array}$ & $\begin{array}{l}\text { BP who } \\
\text { received Usual } \\
\text { care and did } \\
\text { not receive } \\
\text { HAHA } \geq \\
65 y e a r s\end{array}$ & 22 & $\begin{array}{l}M= \\
31.8 \% \\
F= \\
68.2 \%\end{array}$ \\
\hline
\end{tabular}




\begin{tabular}{|c|c|c|c|c|c|c|c|c|}
\hline \multirow{2}{*}{$\begin{array}{l}\text { Author, } \\
\text { Publication } \\
\text { Year }\end{array}$} & \multirow{2}{*}{$\begin{array}{l}\text { Country, } \\
\text { Geographical } \\
\text { Setting }\end{array}$} & \multirow{2}{*}{$\begin{array}{l}\text { Type of RCT \& } \\
\text { Intervention } \\
\text { type, Follow up } \\
\text { period(months) }\end{array}$} & \multicolumn{3}{|l|}{ Intervention Group } & \multicolumn{3}{|l|}{ Control Group } \\
\hline & & & $\begin{array}{l}\text { Population Details, Age } \\
\text { (v) }\end{array}$ & $\begin{array}{l}\text { Sample } \\
\text { Size, } \\
\text { Gender }\end{array}$ & & $\begin{array}{l}\text { Population } \\
\text { Details, Age (y) }\end{array}$ & $\begin{array}{l}\text { San } \\
\text { Gen }\end{array}$ & Size, \\
\hline Wang,2011 & $\begin{array}{l}\text { China- } \\
\text { Guangdong } \\
\text { province, } \\
\text { Shenzhen } \\
\text { Second People's } \\
\text { Hospital }\end{array}$ & $\begin{array}{l}\text { Parallel group } \\
\text { randomised } \\
\text { trial } \\
\text { Educational } \\
\text { intervention } \\
\text { directed to the } \\
\text { patient- } \\
\text { Individual } \\
\text { education was } \\
\text { performed to } \\
\text { inform } \\
\text { participants } \\
\text { about drug } \\
\text { names, } \\
\text { indications, } \\
\text { strengths, } \\
\text { adverse effects, } \\
\text { and usage } \\
\text { instructions. } \\
\text { Pharmacists } \\
\text { also introduced } \\
\text { accurate BP } \\
\text { measurements), } \\
\text { medication } \\
\text { compliance, } \\
\text { healthy lifestyle } \\
\text { behaviours } \\
12 \text { months }\end{array}$ & $\begin{array}{l}\text { BP patients were given } \\
\text { pharmaceutical care } \\
\text { for } 12 \text { months. Patients } \\
\text { randomized to the } \\
\text { intervention group met } \\
\text { with clinical } \\
\text { pharmacists every } 2 \\
\text { months. Individual } \\
\text { education was } \\
\text { conducted to inform } \\
\text { participants about drug } \\
\text { names, indications, } \\
\text { strengths, adverse } \\
\text { effects, and usage } \\
\text { instructions. } \\
\text { Pharmacists } \\
\text { also introduced } \\
\text { accurate BP } \\
\text { measurements (i.e., } \\
\text { body } \\
\text { position, arm position, } \\
\text { cuff placement, and } \\
\text { stethoscope, } \\
\text { cuff size), medication } \\
\text { compliance, healthy } \\
\text { lifestyle } \\
\text { behaviours (i.e., } \\
\text { vegetarian diet, sodium } \\
\text { intake, weight, } \\
\text { and physical activity) } \\
\text { to patients. } \geq 18 y e a r s\end{array}$ & 29 & $\begin{array}{l}M= \\
51.72 \% \\
F= \\
48.2 \%\end{array}$ & $\begin{array}{l}\text { BP patients } \\
\text { were given } \\
\text { regular } \\
\text { medicare, } \geq \\
\text { 18years }\end{array}$ & 30 & $\begin{array}{l}M= \\
46.67 \% \\
F= \\
53.33 \%\end{array}$ \\
\hline
\end{tabular}

\section{Figures}




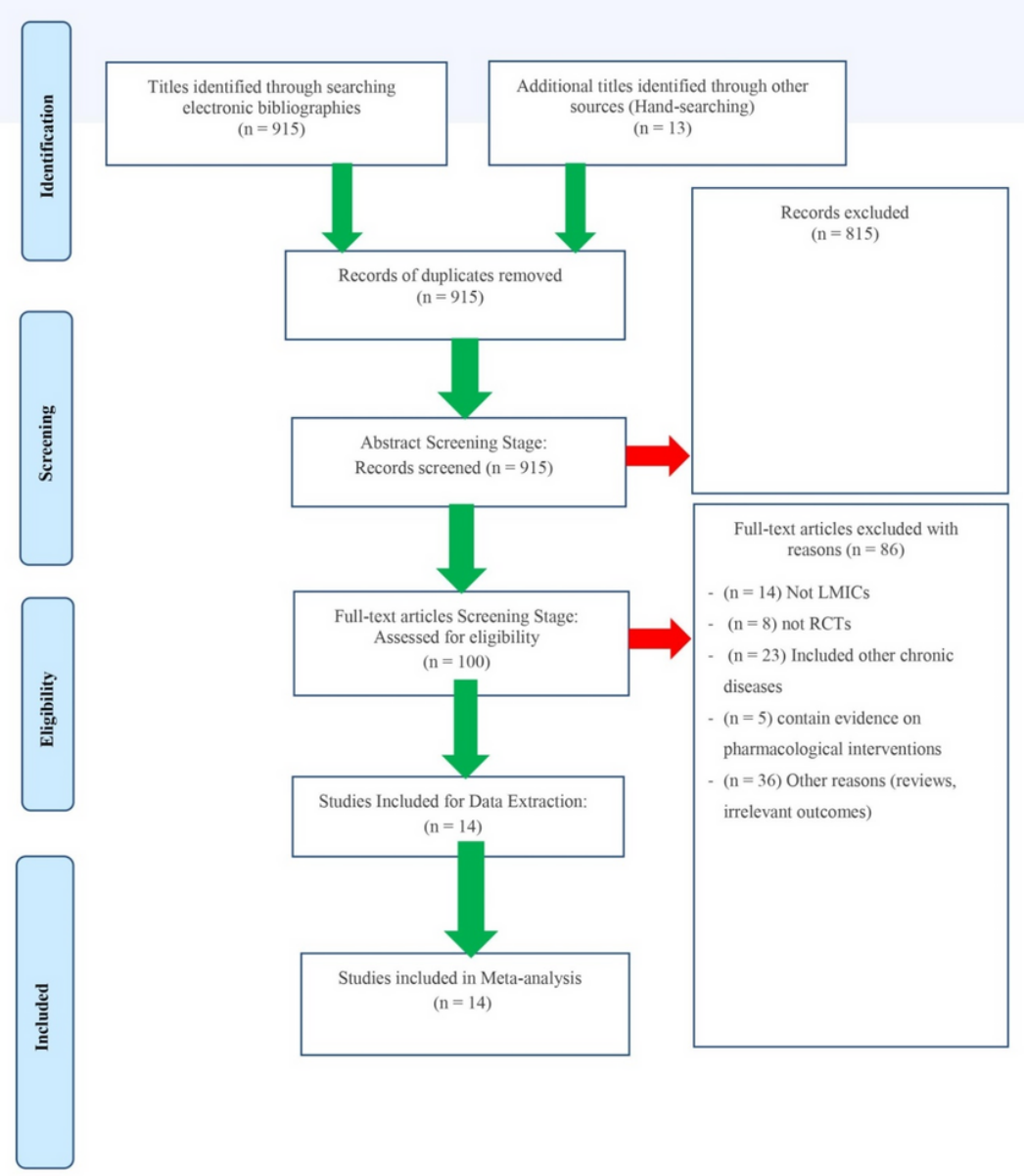

\section{Figure 1}

Preferred Reporting Items for Systematic Reviews and Meta-Analysis (PRISMA) flow diagram of literature search and study selection process 


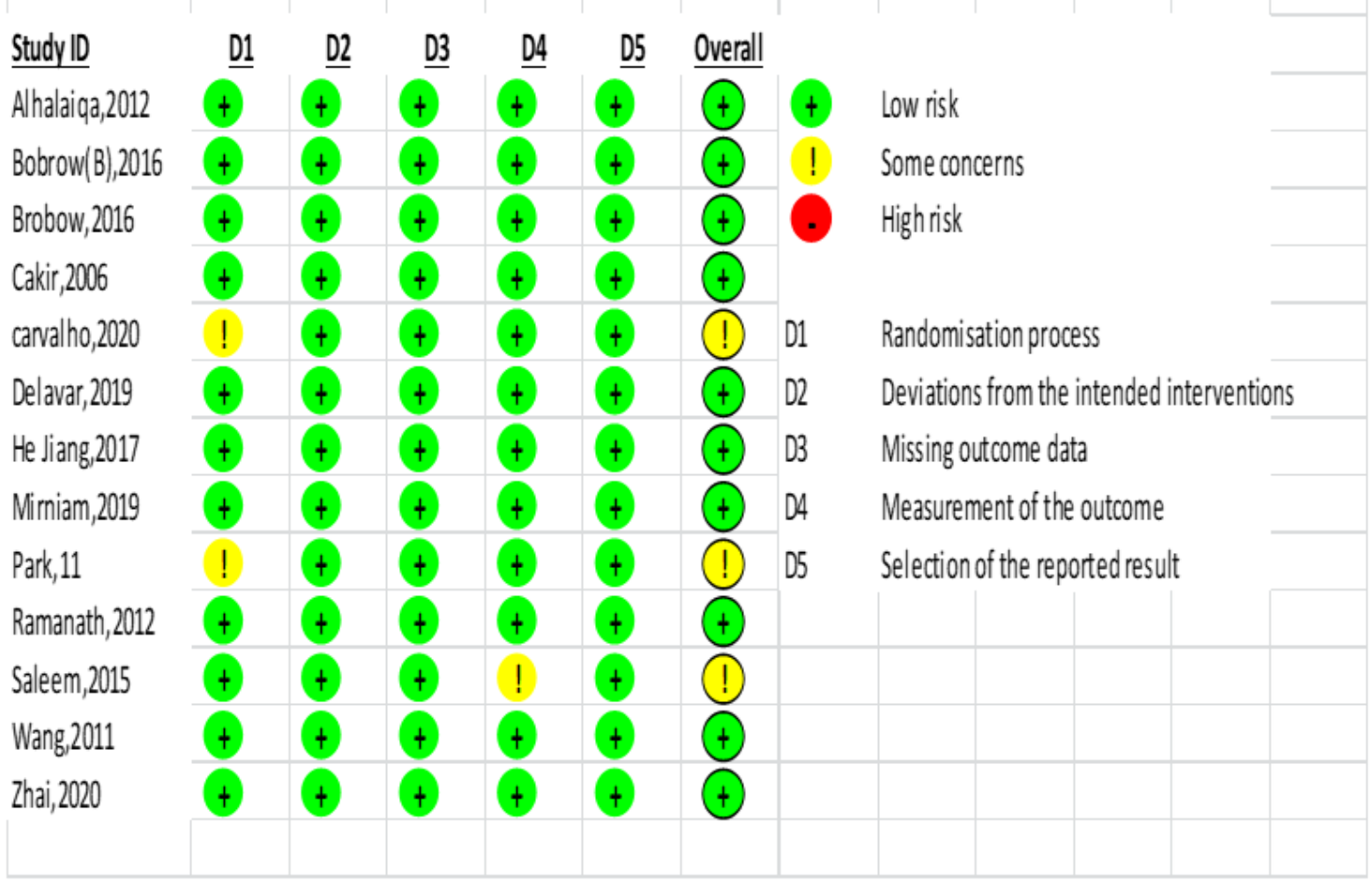

\section{Figure 2}

The methodological quality of results

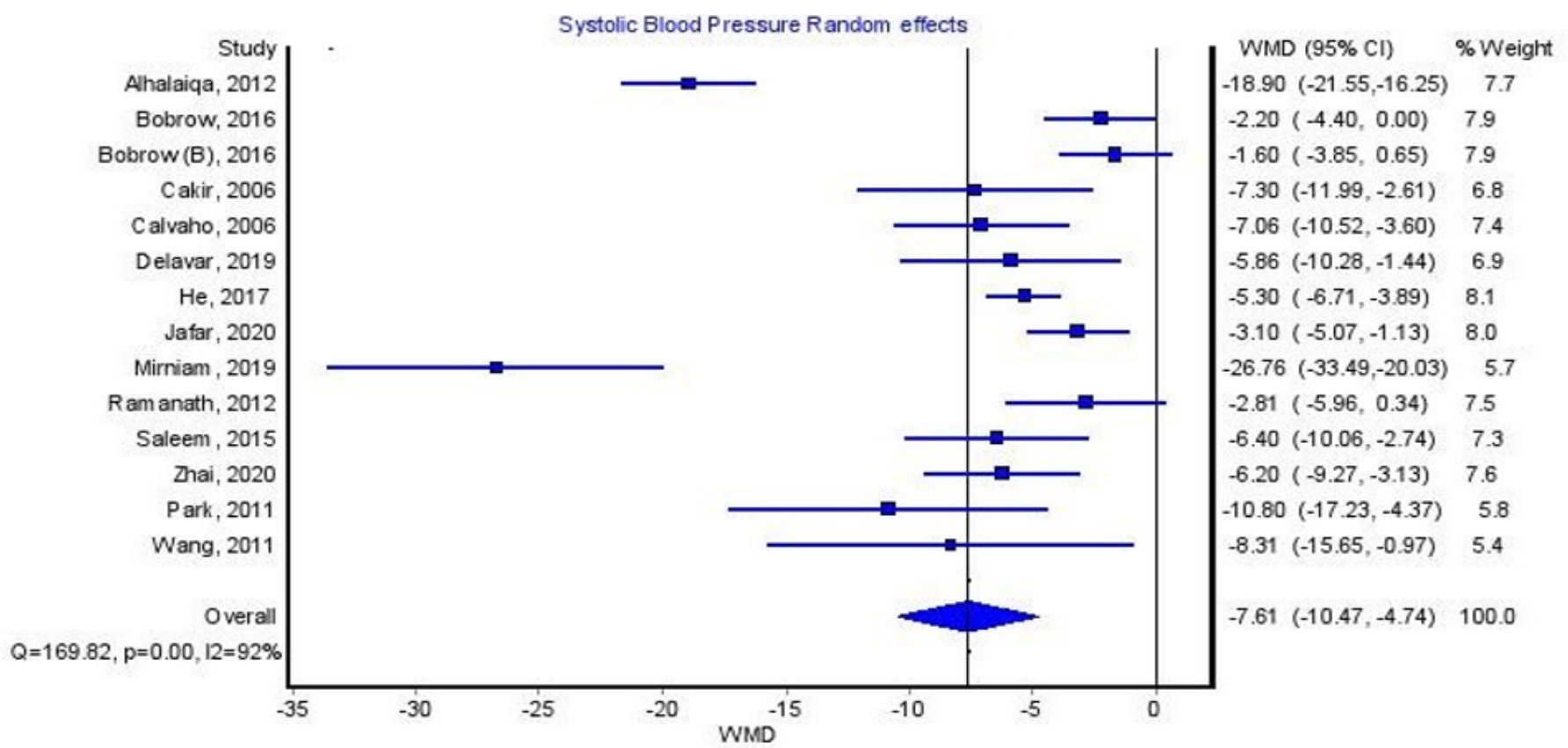

Figure 3

Forest plots of Systolic blood pressure of 14 included studies 


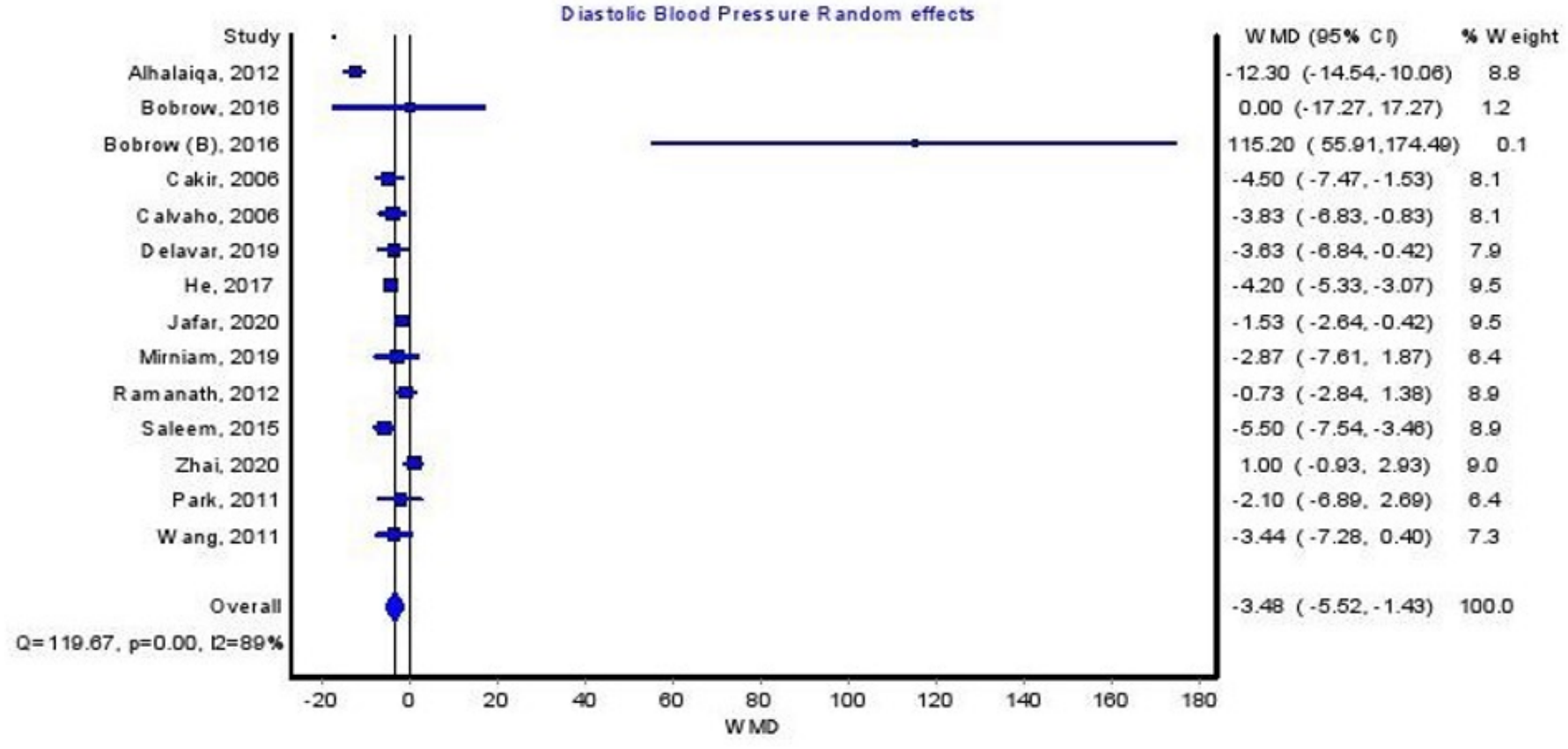

Figure 4

Forest plots of Diastolic blood pressure of 14 included studies

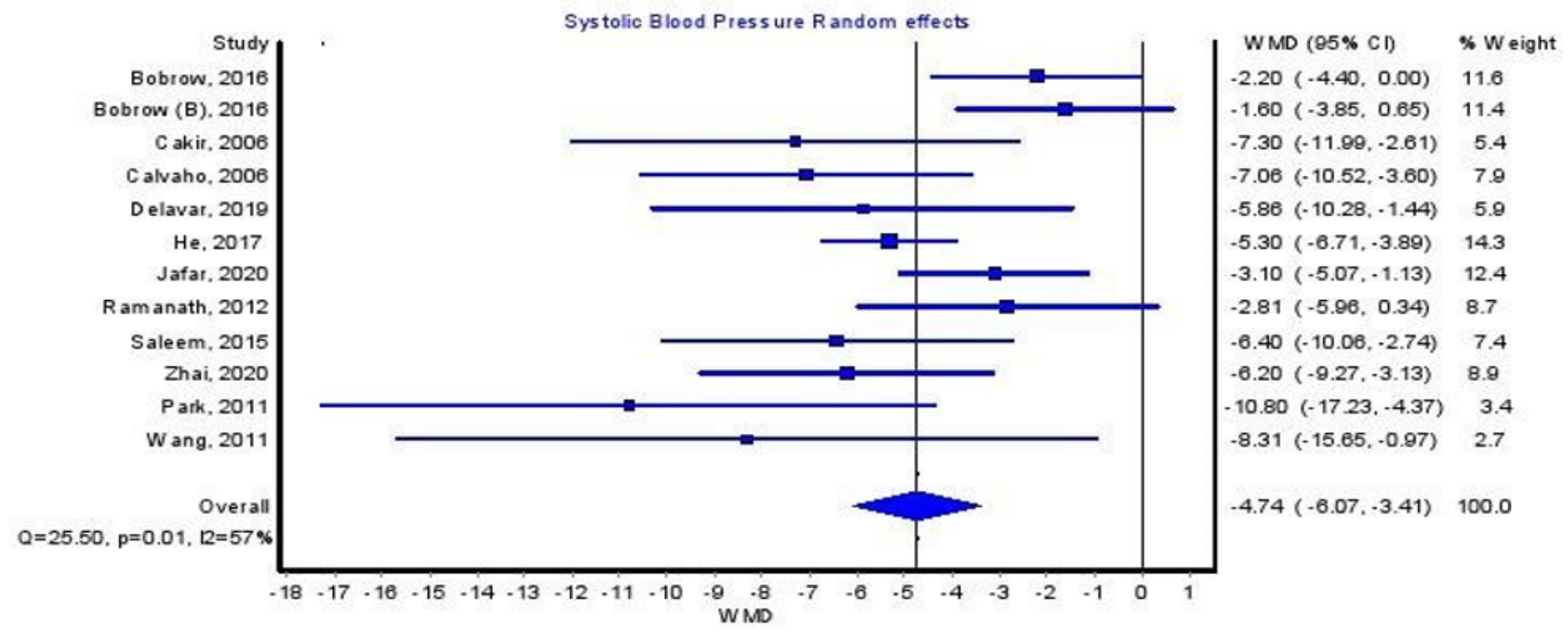

Figure 5

Forest plots for Systolic blood pressure after exclusion of two articles 


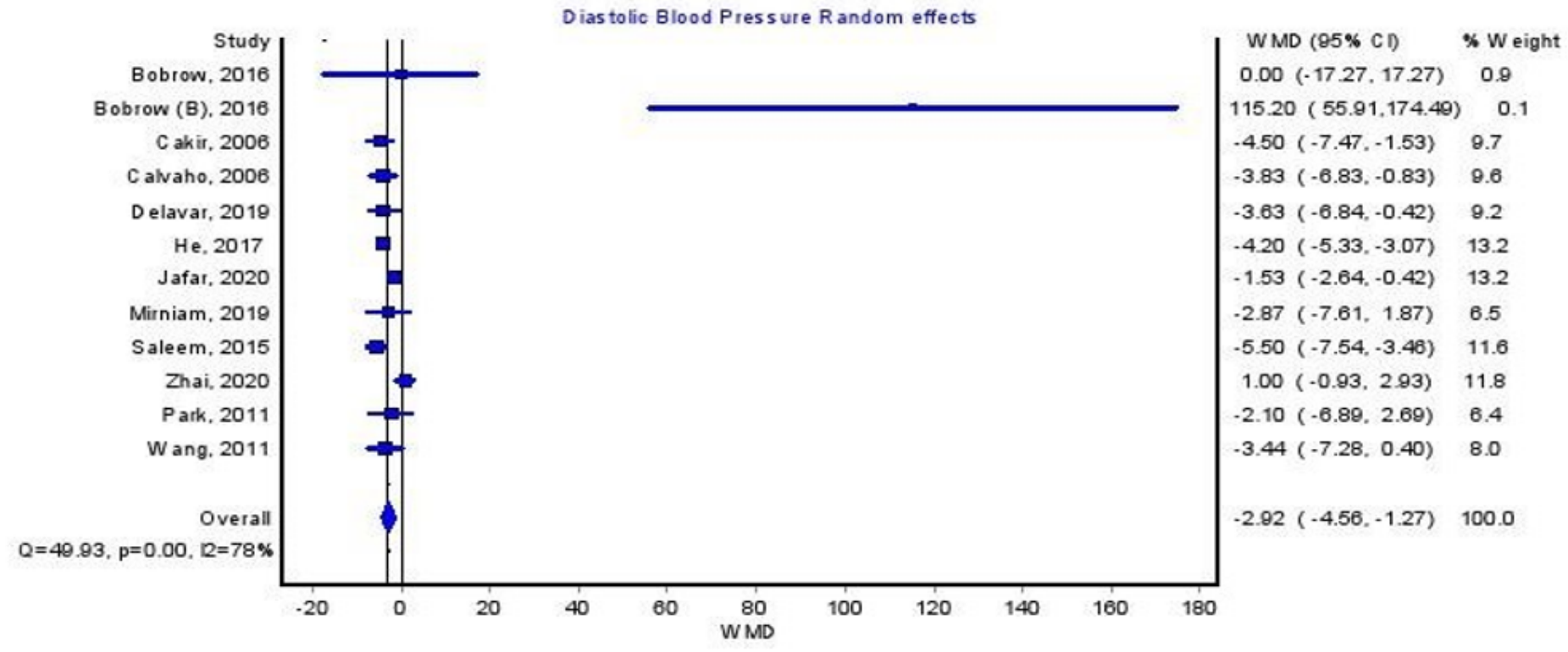

Figure 6

Forest plots for Diastolic blood pressure after exclusion of two articles

\section{Supplementary Files}

This is a list of supplementary files associated with this preprint. Click to download.

- ONakwafilaSupplementaryfiles.docx 